\title{
Strategy of Tourism and Culture Office in Development of Cultural Heritage at Kuantan Singingi Regency
}

\author{
Andri Satria ${ }^{1}$, Moris Adidi Yogia ${ }^{2}$, Zainal $^{3}$, Made Devi Wedayanti ${ }^{4}$ \\ Universitas Islam Riau, Jl. Kaharuddin Nasution No.113 Pekanbaru 28284 Riau \\ andrisatria.pps.uir@gmail.com ${ }^{1}$, moris.adidiy@soc.uir.ac.id², zainal.ip@soc.uir.ac.id ${ }^{3}$, \\ madedeviwedayanti@soc.uir.ac.id ${ }^{4}$
}

\begin{abstract}
Cultural heritage is a material cultural heritage, in the form of building objects, structures, sites, and areas of cultural heritage on land or in water that need to be maintained. The purpose of this study is to determine the Cultural strategy in Kuantan Singingi District. This research method uses qualitative research methods. The results of this study indicate that the strategy of the Department of Tourism and Culture of Kuantan Singingi Regency in the development of Cultural Heritage does not agree, this can be known from the answers of informants related to research and related factors. Head of the Tourism and Culture Office of Kuantan Singingi Regency in developing the Cultural Heritage in Kuantan Singingi Regency. The conclusion of this research is the lack of socialization and non-functioning in the Office of Culture and Services of Kuantan Singingi Regency so that people do not know how the main tasks, functions and lack of tourism management are in Kuantan Singingi Regency
\end{abstract}

Keywords: Cultural Heritage, Tourism and Culture Service Strategy

\section{Introduction}

Cultural heritage buildings are built structures made of natural or man-made objects to meet the needs of walled and / or not walled and roofed spaces. The structure of a cultural preservation is a built structure, made of natural objects, and / or man-made objects to meet the needs of the activity space that is integrated with nature, proposals, and infrastructure to accommodate human needs. Cultural heritage sites are locations that are on land, and in water that contain objects of cultural heritage and structures of cultural heritage as a result of human activities or evidence of past events. Whereas the cultural heritage area is a geographical space unit that has two or more cultural heritage sites which are located close together, and show a characteristic space record.

Care, supervision and data collection on cultural heritage in Kuantan Singingi Regency because they do not have local regulations on cultural heritage and historical objects in Kuantan Singingi District, only refer to regent regulations, and the Culture, Tourism, Youth and Sports Service program of Kuantan Regency Singingi promote the national culture of Indonesia in the midst of world civilization by ensuring the freedom of the people in maintaining and developing their cultural values "so that Indonesian culture needs to be lived by all citizens. Therefore, Indonesian culture that reflects the noble values of the nation must be preserved in order to strengthen the nation's identity, enhance the dignity of the nation, and

strengthen the bond of a sense of unity and unity for the realization of the ideals of the 
nation in the future. Indonesian culture which has noble values must be preserved in order to strengthen the practice of Pancasila, improve the quality of life, strengthen the nation's personality and national pride, strengthen national unity, and improve the welfare of society as the direction of national life.

This research includes the knowledge of cultural heritage and historical tourism, in order to be able to, preserve the nation's cultural heritage and human heritage, enhance the nation's dignity through cultural heritage, strengthen national personality, improve people's welfare and promote national cultural heritage to the international community. which can be used as a tourist attraction, which increases nationalism, the sale value and competitiveness of other regions, and can make the identity of an area, not to preserve cultural heritage and historic objects owned by foreign parties, people often leave knowledge about history, and culture that exist in their own area, especially youth at this time.

\section{Literature Review}

Ali Faried [1] In terminology what is called Administration is managing, managing, managing. If it is affixed with the preposition to each meaning, then it all implies the existence of order and regulation because the target of mastery, management and, moreover, regulation is the creation of order in the dynamic arrangement and regulation. Sergiovanni and Carver [2] said that there are four administrative objectives, namely: work effectiveness, efficiency, adaptability, and job satisfaction. These four objectives can be used as criteria to determine a successful implementation.

So, organizational behavior is a study that involves aspects of human behavior in a particular organization or group. The first aspect includes the influence of organizations on humans, while the second aspect of human influences on organizations. This understanding is consistent with Kelly's formulation in his book Organizational Behavior which explains that organizational behavior in which there are interactions and relationships between organizations on the one hand and individual behavior on the other hand, Wexley and Gary. A [3]. All of these have practical objectives, namely to direct human behavior toward efforts to achieve goals. Management according to Terry in Hasibuan is a typical process, which consists of planning, organizing, mobilizing and controlling actions taken to achieve the goals set through the utilization of human resources and other resources [4].

As mentioned by Daft, management has four functions, namely planning (planning), organizing (organizing), leadership (leading), and controlling (controlling). From the basic functions of management, then follow up after it is known that what has been determined is "achieved" or "not yet achieved", Abdul Choliq [5]. Chandler and Plano [6] Public policy is the use of strategies against existing resources to solve public or government problems. According to him, public policy is a form of state intervention to protect the interests of disadvantaged people.

The criteria for producing information on policy performance are closely related to the criteria for policy recommendations. What distinguishes these criteria for both is the orientation of time, the criterion policy recommendation activities are applied prospectively, while the evaluation activities are retroactive. there are several general aspects in the evaluation (evaluation), namely input, process, output, and outcome [7]. Strategy is a plan and management to achieve certain goals in operational practices (Ruslan, 2007: 37). According to Porter (Rangkuti, 2004: 4) strategy is a very important tool to achieve competitive advantage. 
In line with that, Hamel and Pharalad (Rangkuti, 2004: 4) also said that the strategy is an incremental (continually increasing) action and it is continually carried out based on the perspective of what is expected by customers in the future.

And there is a breakdown of the tasks of the section on the study of history, museums and traditional values according to the Kuantan Singingi District Regulation number 25 of 2009 concerning the elaboration of the duties and functions of the Office of Culture, Tourism, Youth and Sports, article 15 which reads:

a) Carry out the collection, documentation, identification, management and presentation of

historical assessment, museum and traditional value data

b) Prepare materials for the preparation of operational instructions and technical guidelines for the study of history, museums and traditional values

c) Preparing materials for the preparation of program plans and budget assessments of history, museums and traditional values

d) Carry out a mapping of the need for facilities and infrastructure to study history, museums and traditional values

e) Preparing study materials for study of history, museums and traditional values

f) Prepare materials to coordinate the implementation of the task of assessing history, museums and traditional values

g) Preparing materials for developing historical studies, museums and traditional values

h) Prepare materials for supervision and supervision of historical studies, museums and traditional values

Menurut Dr.Moh Hatta Berpendapat Kebudayaan adalah ciptaan hidup dari suatu bangsa. Menurut Djojodigono kebudayaan dengan mengatakan kebudayaan itu adalah daya dari budi, yang berupa cipta, karsa dan rasa [8]. According to Nostrand Defining culture as attitudes and beliefs, ways of thinking, behaving, and remembering together by members of the community [9].According to Larson and Smalley Culture as a "blue print" that guides people's behavior in a community and is incubated in family life. It regulates our behavior in groups, makes us sensitive to issues of status, and helps us know what our responsibilities are to groups, the different cultural underlying structures that make round society and square communities [10].

According to A. Yoeti is a combination of symptoms and relationships that arise from the interaction of tourists, business, the host government and the host community in the process of attracting and serving tourists and other visitors [11]. A. Yoeti Tourism comes from two words, Pari and Wisata. Pari can be interpreted as many, many times, circling or complete. While tourism can be interpreted as a trip or traveling which in this case is synonymous with the word "travel" in English. On that basis, the word "Tourism" can be interpreted as a trip that is made many times or circling from one place to another, which in English is called "Tour" [12]. According to H. Kodhyat is as follows: Tourism is a trip from one place to another, is temporary, carried out individually or in groups, as an effort to find a balance or harmony and happiness with the environment in the social, cultural, natural and scientific dimensions [13].

\section{Research Method}

This type of research uses qualitative research methods, where qualitative research is a research procedure that produces descriptive data in the form of words written or spoken from people and behaves secretly against the background of all individuals (Sugiyono, 2014). This 
research was conducted at the Tourism and Culture Office, Kuantan Singingi Regency, because the Tourism and Culture Office is one of the government institutions tasked with maintaining and maintaining tourism infrastructure, cultural reserves and historic objects in Kuantan Singingi Regency. and enforcing Perbup on Culture and Tourism sites. And several subdistricts and villages that have historical heritage objects, cultural reserves and Tourism Sites.

The type of research in this study is the type of descriptive or qualitative research that is research conducted to determine the value of independent variables, either one variable or more (independent) without making comparisons, or linking one variable with another variable (Sugiyono: 2010: 11) . This research attempts to answer the strategy of the Department of Tourism and Culture in maintaining tourism infrastructure, cultural reserves and historic objects in Kuantan Singingi Regency and what are the obstacles faced in maintaining tourism infrastructure, cultural reserves and historic objects. in Kuantan Singingi Regency.

This research data collection technique is done by interview is used as a data collection technique if the researcher wants to conduct a preliminary study to find problems that must be investigated and also if the researcher wants to know things from the respondents in depth and the number of respondents is small / small (Sugiono: 2011: 157 ). Interviews conducted in this study were by asking questions directly to the research respondents.

\section{Result and Discussion}

Culture is a very broad aspect of knowledge, beliefs, arts, morals and customs or even all habits practiced and possessed by humans as members of the community. society and culture as the historical treasures of a nation / society reflected in their recognition / testimony and values, namely testimony and values which outline for life an ideal goal and spiritual meaning that is free from the contradiction of space and time around. In order to realize the tourist destination, which is cultured and adds knowledge about history.

Cultural Heritage is a material cultural heritage in the form of objects of cultural heritage, cultural heritage buildings, structures of cultural reserves, cultural heritage sites, and areas of cultural heritage on land and / or in water that need to be preserved because they have important values for history, science, education, religion and / or culture through the process of determination. Cultural Heritage Property Natural objects and / or man-made objects, both movable and immovable, in the form of a unit or group, or parts thereof, or the remnants that have a close relationship with the culture and history of human development. The building of cultural preservation built with natural objects or man-made objects to meet the needs of walled and non-walled, roofed spaces The structure of cultural preservation structures that are made of natural objects and / or man-made objects to meet the needs of activity space which is integrated with nature, facilities, and infrastructure to accommodate human needs.

Tourism is a geographical area within one or more administrative areas within which there is a tourist attraction, public facilities, tourism facilities, accessibility and the community that are interrelated and complete the realization of tourism. With the arrival of tourists is expected to open economic opportunities / employment opportunities for the community, as well as an increase in regional income which has implications for improving people's welfare.Tourism object development must not be in conflict with religion and culture to explore, develop and preserve tourism potential in a planned and sustainable manner. 


\section{Dimensions of Preservation}

Preservation is protection from destruction or preservation of conservation and management of natural resources that guarantees their use wisely and guarantees continuity of supply by maintaining and enhancing the quality of values and diversity, as well as efforts to protect the ability of negative impacts caused by an activity and maintain environmental stability, the Office of Tourism and Culture of Kuantan Singingi Regency, made several efforts contained in the mission of the Department of Tourism and Culture, namely:

a) Increasing human resources in the field of tourism that can manage the potential of culture, art and nature that have become the object and destination of domestic and foreign tourism.

b) Explore, develop, develop and preserve the tourism potential of Kuantan Singingi in a planned and sustainable manner.

c) Promotes broadly about Tourism in Kuantan Singingi Regency at the local, national, regional and international levels.

d) Develop and enforce regulations on the exploitation of the tourism sector in the framework of supervision and order as well as optimizing local revenue.

Therefore, the Department of Tourism and Culture must be able to carry out their duties in order to realize the mission of the Office of Tourism and Culture in preserving cultural heritage in Kuantan Singingi Regency. Based on the respondent's answer, it can be seen that the Office of Tourism and Culture of Kuantan Singingi Regency has not performed its duties in accordance with procedures so that they are not in line with what is expected by the general public. The statement given by the community is very contrary to what the author listens to from government agencies, namely when the writer interviewed the Head of Tourism and Culture, Mr. Indra Suandi, stated that the Office of Tourism and Culture has been preserving cultural heritage based on the results of a feasibility study that can be academically accountable, technical and administrative states that: "On behalf of the Department of Tourism and Culture, in preservation of cultural heritage we always conduct site reviews, such as the preservation of historic objects from the kingdoms that once existed in singing singing as well as historical objects during the colonial period, such as traditional houses, musical instruments, instruments of war, the existence of paths, and the existence of other cultural reserves, such as repairing traditional halls, pencak silat pages, but based on annual proposals, it is not routine because we are just trying to cultivate the local culture in the area that we have to lift into a local atmosphere. this is what we have developed in stages which has been done by the Department of Tourism and Culture and we will prove it academically.

From the responses of respondents above answered about the preservation of cultural preservation has been coordinating in accordance with conservation experts by the Department of Tourism and Culture in accordance with its function stated less agree from 26 respondents there were 15 respondents answered less agree or $57.8 \%$. Each government agency must carry out its duties and functions in accordance with the applicable local laws and regulations. So that the community feels the use of these agencies and the community is not disappointed because of the lack of socialization, due to the very minimal Kuantan Singingi Regency government budget at this time. The Department of Tourism and Culture, the author found its function in the development of traditional cultural values in Kuantan Singingi Regency, but it was not in accordance with what was done in the community at large. Likewise with the results of interviews conducted by the author to the Head of the Department of Tourism and Culture Indra Suandi.

"Actually we have tried and have a discourse on the preservation of traditional cultural 
heritage and have coordinated with related parties such as archaeologists, the Provincial Culture Office and the ministry and we are coordinating with the government of Kuantan Singingi Regency, but so far the Kuantan Singingi District Government has limited limitations. available, that is, from human resources and a very minimal budget for treating these cultural values, because we cannot deny that in the development we must need a sizable budget, therefore so far the Department of Tourism and Culture has not done as much as possible to develop the traditional cultural values of Kuantan Singingi Regency, and myself as the head of the office have not been here for a year".

The table above shows that the respondent stated less achieved if the Department of Tourism and Culture, has preserved cultural heritage and considered the possibility of returning to the initial condition, because of the 26 respondents there were 18 people or $69.4 \%$ who stated less achieved. The government must be careful in this matter, especially the Office of Tourism and Culture, so that the preservation of cultural heritage is carried out and consider returning the cultural heritage to its initial condition, so that regional characteristics remain, and the community knows the cultural heritage and the public knows the history in the Kuantan Singingi area, so that the region Kuantan singing can be used as a tourist attraction to improve the economy of the Kuantan singing community.

When the authors interviewed the head of the sect's section of cultural heritage Ratna Sari about considering the possibility of returning to the initial conditions as before conservation activities. "We from the Department of Tourism and Culture, have collected data on cultural reserves and historical objects in Kuantan singing district, which is located in 15 sub- districts in Kuantan singingi district, starting from the bottom of the Jambi area to Cerenti, which is like the cultural heritage of the kingdom of Candis, it can be proven through stone inscribed with sanskrit writings, and recently discovered tombstone- shaped artifacts, if examined, these objects have existed since the 2 nd century AD of the royal era, and there are like steel tanks and tombs of historical figures, but only data collection is not preserved because there are no rules regional governing, the Office only refers to Law No. 11 of 2010 concerning cultural heritage".

From the responses of the respondents above about the preservation of cultural heritage which has been supported by documentation activities carried out by employees of the Department of Tourism and Culture based on the place of cultural heritage contained in 15 subdistricts of Kuantan singingi district agreed that because of the 26 respondents there were 12 people or $46.1 \%$ who agreed.

In accordance with the function of the Department of Tourism and Culture about the assessment of history, museums and traditional values point a in article 15, namely: Carry out the collection of documentation, identification, management and presentation of historical assessment data, cultural heritage, museums and traditional values. Based on the function of the study of history, museums and traditional values, the Department of Tourism and Culture must carry out their obligations in accordance with existing provisions so that the public knows the cultural and historical heritage in Kuantan Singingi Regency. When the writer interviewed the Secretary of the Office of Tourism and Culture Suhardi he stated:

"We have done the documentation of cultural heritage, not only our documentation has also collected cultural heritage data collection such as the canon of the king of Ismail in the lower Kuantan sub-district of Seberang and the tombs of the figures in 15 subdistricts, but we are constrained by the community's response that is not want the objects of cultural preservation to be preserved, because there are some cultural reserves that are stored by the public and people do not want the objects to be placed in one place, we don't have museums at all, only the discourse for making the museum already exists ". 
When the writer asked to consider the possibility of returning to the initial conditions as before the conservation activities Indra Suandi mentioned: "Our goal is to explore cultural values so that they can be maintained, so that values can be sustained in the future when our children and grandchildren will be able to know and enjoy them, physically we will revitalize the cultural heritage to its original form, such as traditional houses, we are from the Department of Tourism and Culture, has collected data on cultural reserves and historical objects in the Kuantan singing district, which is located in 15 sub-districts in Kuantan singingi district, starting from the Lubuk jambi area to Cerenti, which is like the cultural heritage of the kingdom of Candis, can be proven through the stone written with sangsakerta writings There are steel tanks and tombs of historical figures, but data collection is not preserved because there are no local regulations governing, the Office only relies on Law No. 11 of 2010 concerning cultural heritage.

\section{Conclution}

From the results of the field research shows that the development of cultural heritage in the Tourism and Culture Office of Kuantan Singingi Regency, stated that it was less agreed/not maximized, because in the development of cultural heritage in the Tourism and Culture Office of Kuantan Singingi Regency, it had not been carried out in accordance with what was expected by the community such as the lack of socialization carried out, Care and Protection of cultural reserves as well as many cultural reserves that are not saved due to lack of awareness of the Department of Tourism and Culture of Kuantan Singingi District so that people are less aware of the history of Kuantan singingi district and the locations of cultural heritage in Kuantan Singingi District, which can be used as objects cultural tourism and improve the regional economy and society in tourism, in accordance with Indonesia's current motto that is "wonderful Indonesia" Riau especially Kuantan Singingi has a cultural preservation that can be used as a tourist attraction.

Tourism and Culture Office of Kuantan Singingi Regency In carrying out their duties and functions the Tourism and Culture Office must pay attention to existing provisions, such as the regulations of the Regent of Kuantan Singingi Regency so that there is no ignorance in the community of cultural and historical heritage. And cause a sense of wanting to keep protecting and preserving the cultural heritage. As a good citizen the community must obey all applicable rules in the country, in the development of cultural heritage the community should know and protect the cultural heritage, and people who have cultural heritage must maintain, protect, preserve and inform the Department of Tourism and Culture in order to maintain it cultural and historical heritage that is characteristic of Kuantan Singingi Regency. Because good cooperation from the government with the support of the community will certainly improve the welfare of the Indonesian people, especially in cultural and historical heritage.

\section{References}

[1] Ali, Faried. 2011. Teori dan Konsep Administrasi Jakarta: Raja Grafindo Persada.

[2] Daryanto, H.M. 2006. Administrasi Pendidikan, Jakarta: PT Rineka Cipta

[3] Kansil, C.S.T. 2005. Sistem Pemerintahan Indonesia edisi revisi: Bumi Aksara, Jakarta.

[4] Hasibuan, Malayu. 2001. Manajemen Sumber Daya Manusia. Jakarta: PT. Toko Gunung Agung. 
[5] Choliq, Abdul. 2011. Pengantar Manajemen. Semarang: Rafi Sarana Perkasa.

[6] Hakim, EM.Lukman. 2011. Pengantar Administrasi Pembangunan. Jogyakarta: Ar-Ruzz Media

[7] Wiratama, A. 2016. Dampak Implementasi Program Minapolitan Terhadap Kesejahteraan Masyarakat Di Kecamatan Muncar Kabupaten Banyuwangi. Kebijakan dan Manajemen Publik, 4(3)

[8] Djojodigoeno, M.M. (1958). Azas-Azas Sosiologi. Dalam buku Folklor Indonesia, Danandjaja, James, Jakarta;

[9] Definisi Kebudayaan. 2011, diakses 03 Maret 2019 from: https://mediabacaan.blogspot.com/2011/03/definisi-kebudayaan-menurut-para-ahli.html

[10] Larson, D.N., \& Smalley, W.A. 1972. Becoming bilingual. A guide to language learning. New Canaan, CT: Practical Anthropology

[11] Yoeti, Oka A. 1993. Pengantar Ilmu Pariwisata. Bandung: Angkasa

[12] H.Kodhyat. 1983. Sejarah Pariwisata dan Perkembangannya di Indonesia. Jakarta: PT. Gramedia Pustaka Utama.

[13] Castaneda, Nestor, 2016. Business Coordination and Tax Politics, Political Studies, 1-22. Terindex Scopus Q1. 